DOI https://doi.org/10.18551/rjoas.2017-12.09

\title{
THE EFFECT OF ORGANIZATIONAL CULTURE AND WORKING ENVIRONMENT ON EMPLOYEE PERFORMANCE: STUDY ON THE EXAMPLE OF PRINTING COMPANY
}

\author{
Zainul Mohammad \\ Management Department, Faculty of Economics, \\ University of Islam Kalimantan-Muhammad Arsyad Al Banjari, Indonesia \\ E-mail: zainul38@yahoo.co.id
}

\begin{abstract}
The main objective of this research is to examine and analyze how the organizational culture influences on the performance of the employees of Banjarmasin Post Group, and find out how the work environment has influence on the performance of its employees. Involved sample in this studies are 100 employees across all departments. The proposed model indicates that it can deliver the dependent variable by $71 \%$ by the quite strong relation at 0.846 . The finding indicates that significant effect is occurred on working environment while the organizational culture doesn't contribute any significant effect on employee performance. However, the simultaneous effect indicates that both variables were affecting employee performance.
\end{abstract}

\section{KEYWORDS}

Employee, engagement, print business, performance, organization.

Every organization or company needs production factor namely resources to achieve its goals. Resource implied in this topic is consist of source of energy, energy, power needed to create power, motion, activity, activity and action. In terms of company production resources consist of natural resources, financial resources, human resources, science resources and technological resources.

Business competition today is becoming rough and hard to be entered. Company success factor is depends on the quality of human resources who run it. Generally every company has the same goal which is maintain the life-cycle and performance of the company. The successful company is inseparable from the role of qualified human resources that run all the systems within the company. The most important resource of a company or organization is the human resources of the person who has provided their energy, talents, creativity and effort to the organization (Handoko, 2001). Therefore, the advancement of a company can be determined from human resources capable of performing the best performance of each individual.

Humans always play an active role in determining plans, systems, processes, goals to be achieved by the company (Hasibuan, 2011). Goals cannot be realized without the employee's role, although the support of facilities and infrastructure and the source of funds owned by the company will not be of benefit to the company, if the employee's active role is excluded. Employee is a key element of the organization. The success or failure of the organization depends on employee performance. Therefore, organizations are investing huge amount of money on employee development (Sheikh et al., 2017). There are several studies that develop the process for developing employee performance that are aligned with organizational goals (Development, 2011). Prior research found that organizational culture has significant effect on employee job satisfaction.

\section{LITERATURE REVIEW}

Organizational culture can be characterized as the common, fundamental suspicions that an organization learnt while adapting to the environment and tackling issues of external adjustment and internal cooperation that are instructed to new individuals as the right approach to take care of those issues (Yoo and Park, 2007). Each employer has its specific 
culture, which develops time beyond regulation to mirror the company's identity in dimensions: seen and invisible (McDermott and O'Dell, 2001). The visible size of subculture is contemplated within the espoused values, philosophy and assignment of the firm at the same time as the invisible measurement lies in the unspoken set of values that manual employees' moves and perceptions inside the corporation (Hong, Suh and Koo, 2011). Organizational factor is introduce in 2002 consist of organization structure, information systems, people, reward system, leadership and processes (Gupta and Govindarajan, 2000). The finding on prior research indicates that the strong culture of an organization based upon managers and leaders help in improving level of performance. Managers relate organization performance and culture to each other as they help in providing competitive advantage (Awadh and Saad, 2013). Finding also shows that factors such as empowerment and recognition increase employee motivation. If the empowerment and recognition of employees is increased, their motivation to work will also improve, as well as their accomplishments and the organizational performance (Dobre, 2013). Based on those prior researches the hypotheses were drawn as follow:

$H_{1}$ : Organizational culture affecting employee performance.

Work environment in the company also affects the performance carried out by employees. This work environment itself consists of physical and non-physical attached to the employees was inseparable from the business development of employee performance (Gruman and Saks, 2011). A fresh, comfortable and fulfilling work environment that meets the standards of worthy needs will contribute to the employee's comfort in doing his job. Nonphysical work environments that include the hospitality of employee attitudes, mutual respect at different times of opinion, etc. are mandatory requirements to continuously foster the quality of employee thinking that can ultimately foster their performance on an ongoing basis (Solomon et al., 2012). Study on small scale company indicate that special focus and effort is required specifically on the factors working-environment and team and co-worker relationship as they have shown significantly higher impact on employee engagement and hence employee performance (Anitha, 2014).

$\mathrm{H}_{2}$ : Working Environment affecting employee performance.

\section{METHODS OF RESEARCH}

Type of research used by the researcher in this study is quantitative research which use research model that requires the existence of the calculation of the numbers, while the approach used is survey-approach that is the research taking samples from the population and using the questionnaire as the main data collection tool (Singarimbun, 1970; Singarimbun and Effendi, 2011; Creswell, 2013).

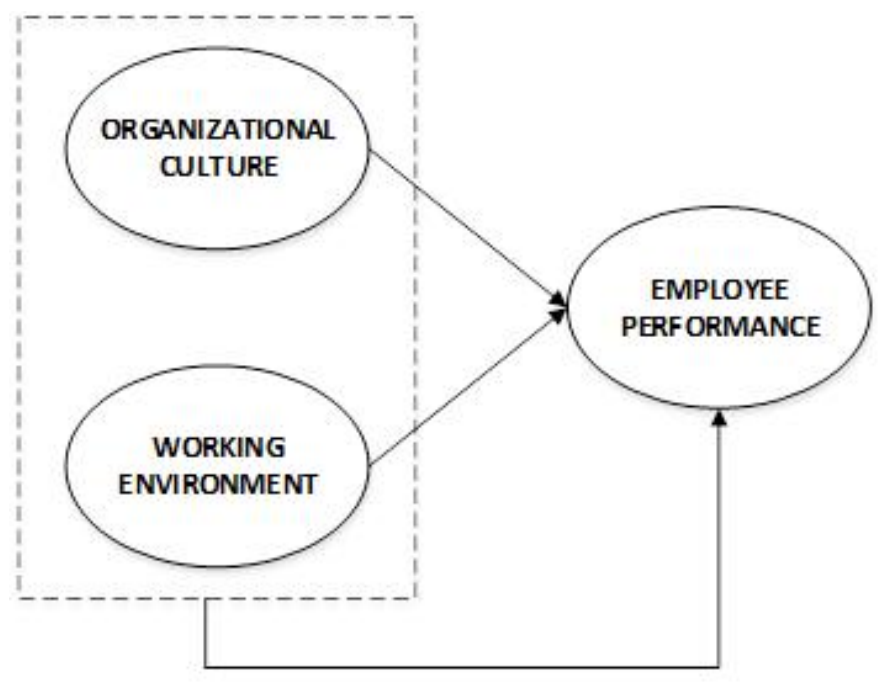

Figure 1 - Proposed Model 
To facilitate the justification of employee perceptions is used 5 points Likert scale which require unique data analysis procedures, and as a result, misuses and/or mistakes often occur (Boone and Boone, 2012).

The object of this research is Banjarmasin Post Group (B. Post). Members of the population in this study were all employees of Banjarmasin Post Group (B. Post). In this study the sample was determined as many as 100 respondents by using stratified random sampling.

Inferential analysis is intended to examine the hypothesis proposed in the study, which is by using Multiple Linear Regression Method and overall data analysis implemented by using computer program statistics SPSS for Windows.

\section{RESULTS AND DISCUSSION}

Collected data examine both using descriptive analysis and inferential analysis. Descriptive analysis is aimed to get a central value of research respondent on proposed questionnaire. Table 1 shows the mean of each item and the variable mean.

Table 1 - Descriptive Statistics Resume

\begin{tabular}{lc}
\hline \multicolumn{1}{c}{ Variable/ Item } & Item Mean \\
\hline Organizational Culture & 3.89 \\
1. Complete the work differently & 3.73 \\
2. Advising opportunity & 3.74 \\
3. Employee ability in completing the task & 3.71 \\
4. Willing to listen to suggestions & 3.74 \\
5. Helping other employees & 3.71 \\
Working Environment & 3.73 \\
1. Comfortable with working atmosphere & 3.75 \\
2. Willing to provide assistance to colleagues if needed & 3.60 \\
3. Facilities in the workplace are adequate & 3.67 \\
4. Workplace facilities are complete and comfortable & 3.692 \\
5. Every employee has a working uniform & 3.75 \\
Employee Performance & 3.69 \\
1. Every employee finishes the job neatly and thoroughly & 3.57 \\
2. subordinate never complain about the work & 3.79 \\
3. Quality of work is correspond with determined standards & 3.75 \\
4. Employees can achieve determined targets & 3.710 \\
5. Employees may exceed the target & \\
\hline
\end{tabular}

Source: SPSS Output.

Table 2 - Regression Output of Partial Examination

\begin{tabular}{cccccc}
\hline \multirow{2}{*}{ Mode } & & \multicolumn{2}{c}{ Unstandardized Coefficients } & \multirow{2}{*}{ S } & Sig. \\
\cline { 3 - 4 } & & $\mathrm{B}$ & Std. Error & & \\
\hline \multirow{2}{*}{1} & (Constant) & .489 & .232 & 2.111 & .037 \\
& Organizational Culture & .052 & .089 & .589 & .557 \\
& Working environment & .800 & .080 & 9.952 & .000 \\
\hline
\end{tabular}

Source: SPSS Output.

Table 3 - ANOVA output of Simultaneous Examination

\begin{tabular}{ccccccc}
\hline Model & & Sum of Squares & df & Mean Square & F & Sig. \\
\hline \multirow{2}{*}{1} & Regression & 38.925 & 2 & 19.463 & 122.533 & $.000(\mathrm{a})$ \\
& Residual & 15.407 & 97 & .159 & & \\
& Total & 54.332 & 99 & & & \\
\hline
\end{tabular}

Source: SPSS Output.

Table 4 - Model Summary

\begin{tabular}{ccccc}
\hline Model & $\mathrm{R}$ & $\mathrm{R}$ Square & Adjusted R Square & Std. Error of the Estimate \\
\hline & R Square Change & F Change & df1 & df2 \\
\hline 1 & $.846(a)$ & .716 & .711 & .399 \\
\hline
\end{tabular}

Source: SPSS Output. 
From the constant table it was obtained a number of 0.489 which means without any contribution of organizational culture and working environment, the employee performance measured as many as 0.489 .

From the organizational culture contributing as many as 0.052 on employee performance for every 1 point of change in organizational culture. The $t_{\text {calc }}$ shows a nonsignificant effect of organizational culture on employee performance. Which means that the proposed hypothesis is not supported.

Working Environment contribute as many as 0.800 on employee performance for every 1 point of change in working environment. The sig column shows an expected probabily of 0.000 (alpha 0.05) regarded as a significant effect on employee performance.

From ANOVA table it was obtained that the $F_{\text {calc }}$ is more than $F_{\text {table }}$ by the probability of 0.000 (alpha 0.05) which is means that simultaneously both organizational culture and working environment is affecting the employee satisfaction. It means that organizational culture can't be a sole indicator in predicting the employee satisfaction.

From the model summary table it can be drawn that the model (Organizational Culture and working environment) can explain the predictor of employee performance as many as $71.6 \%\left(R^{2}=0.716\right)$ which the rest are predicted by other variables beyond this study.

The relationship of independent and dependent variable were categorized as strong enough as many as 0.846 which closest to 1 .

\section{RESEARCH LIMITATION}

The great results of model examination don't merely determine the perfect results. The difficulties to combine prior studies as a research base-line sometimes make the model development more difficult to get done. This research was done on a specific company so the degree of generality may results a less compatibility on another object. Further research need to include more variable and indicator and gaining a wider object and sample criteria.

\section{CONCLUSION AND RECOMMENDATIONS}

This research examines the effect of organizational culture and working environment on employee performance. The study was conducted at national printing business at south Kalimantan business unit namely Banjarmasin Post Group (B-Post). Both variable indicate a simultaneous effect on employee performance while partially, it was only the working environment that affect the employee performance. However, since the organizational culture doesn't indicates any significant effect on employee performance, it shows a great results from employee's responses. It can be drawn from the descriptive statistics that indicates most of the item means was at level 4 and so do with the variable means. This finding is supported by the prior research the results doesn't merely make the organizational culture code-of-conduct were poorly applied. It can indicate that the organizational culture were already settled down in this organization, so any improvement of organizational culture would not give any further impact on employee performance (Solomon et al., 2012; Muogbo, 2013; Zameer et al., 2014).

However, there is no research without any limitation. There are several limitation in this study as recommendation for future research. This research is limited on specific industry and specific object since there was little large printing business in the area. Thus the wider scope of sample is necessary for greater degree of generality against particular theories. The more involved indicator in this research and employing structural model would make the finding richer in the future.

\section{ACKNOWLEDGEMENTS}

This study was done in collaboration between researcher and UNISKA Community Service and Research Bureau (LPPM-UNISKA). Researcher conveying a great appreciation 
to Director of UNISKA Community Service and Research Bureau, who was supporting this examination in program of 2017.

\section{REFERENCES}

1. Anitha, J. (2014) 'Determinants of employee engagement and their impact on employee performance', International Journal of Productivity and Performance Management, 63(3), pp. 308-323. doi: 10.1108/IJPPM-01-2013-0008.

2. Awadh, A. M. and Saad, A. M. (2013) 'Impact of Organizational Culture on Employee Performance', International Review of Management and Business Research, 2(1), pp. 168-175.

3. Boone, H. N. J. and Boone, D. A. (2012) 'Analyzing Likert data', Journal of Extension, 50(2), p. 30. doi: 10.1111/j.1365-2929.2004.02012.x.

4. Creswell, J. W. (2013) Research Design: Qualitative, Quantitative, and Mixed Methods Approaches, Research design Qualitative quantitative and mixed methods approaches. doi: 10.1007/s13398-014-0173-7.2.

5. Development, E. R. and E. (2011) 'Handbook for a measuring employee performance', Workforce Compensation and Performance Service, 1, p. 84.

6. Dobre, O. (2013) 'Employee motivation and organizational performance', Review of applied socio-economic research, 5(1), pp. 53-60.

7. Gruman, J. A. and Saks, A. M. (2011) 'Performance management and employee engagement', Human Resource Management Review, 21(2), pp. 123-136. doi: 10.1016/j.hrmr.2010.09.004.

8. Gupta, A. K. and Govindarajan, V. (2000) 'Knowledge Management's Social Dimension: Lessons from Nucor Steel', MIT Sloan Management Review, 42, pp. 71-80.

9. Handoko, T. H. (2001) Manajemen personalia dan sumberdaya. 2nd edn. Yogyakarta.

10. Hasibuan, M. S. P. (2011) 'Manajemen Sumber Daya Manusia', Edisi Revisi Jakarta: Bumi Aksara. doi: 10.1017/CBO9781107415324.004.

11. Hong, D., Suh, E. and Koo, C. (2011) 'Developing strategies for overcoming barriers to knowledge sharing based on conversational knowledge management: A case study of a financial company', Expert Systems with Applications, 38(12), pp. 14417-14427. doi: 10.1016/j.eswa.2011.04.072.

12. McDermott, R. and O'Dell, C. (2001) 'Overcoming cultural barriers to sharing knowledge', Journal of Knowledge Management, 5(1), pp. 76-85. doi: 10.1108/13673270110384428.

13. Muogbo, B. U. (2013) 'The Impact of Employee Motivation on Organizational Performance (A Study of Some Selected Firms In Anambra State Nigeria)', The International Journal Of Engineering And Science, pp. 2319-1813. Available at: www.theijes.com (Accessed: 19 September 2017).

14. Sheikh, Z. et al. (2017) 'Acceptance of social commerce framework in Saudi Arabia', Telematics and Informatics. doi: 10.1016/j.tele.2017.08.003.

15. Singarimbun, M. (1970) 'Economic aspects of family planning', Bulletin of Indonesian Economic Studies, pp. 102-105. doi: 10.1080/00074917012331331738.

16. Singarimbun, M. and Effendi, S. (2011) Metode Penelitian Survei. 4th ed. Jakarta: Pustaka LP3ES.

17. Solomon, O. et al. (2012) 'Employee Motivation and Organizational Performance in Multinational Companies: A Study of Cadbury Nigeria PIc', IRACST-International Journal of Research in Management \& Technology, 2(3), pp. 2249-9563. Available at: http://eprints.covenantuniversity.edu.ng/4967/1/Employee Motivation and Org Performance.pdf (Accessed: 19 September 2017).

18. Yoo, D. K. and Park, J. A. (2007) 'Perceived service quality', The International Journal of Quality \& Reliability Management, 24(9), pp. 908-926.

19. Zameer, H. et al. (2014) 'The Impact of the Motivation on the Employee's Performance in Beverage Industry of Pakistan', International Journal of Academic Research in Accounting Finance and Management Sciences, 4(1), pp. 293-298. doi: 10.6007/IJARAFMS/v4-i1/630. 